\title{
THE THREE DIMENSIONS OF CHINA THREAT TO JAPAN'S NATIONAL SECURITY ${ }^{1}$
}

\author{
Lee Chee Leong and Md Nasrudin Md Akhir
}

\begin{abstract}
This paper provides a comprehensive outlook of the Japanese perception of China's expansionist threats to Tokyo's national security. In doing so, three dimensions of China threat, namely, Beijing's military ascendancy, mounting Chinese civilian and maritime enforcement activities in the contended East China Sea, and mainland's growing military influence over Taiwan, are examined in relations to Japan's military, political and economic security in the region. The paper concludes that as far as the Japanese administration is concerned, China's expansionism is a phenomenon that threatens Japan's national security in a multi-dimensional way.
\end{abstract}

Keywords: China's rise, China threat, Japan's national security, East China Sea, military modernization,Taiwan issue

\section{Introduction: The Japanese Perception of the China Threat}

The rise of China is a multi-faceted phenomenon that has sparked conventional security concerns in the East Asian region. In the words of scholar Jiang Ye, the perception of threat takes precedence over the threat itself, in inducing individual states to adopt and pursue particular foreign policies internationally. ${ }^{2}$ For a country like Japan that is yet to attain a "normal" military state but still has to co-exist with potential threats in Northeast Asia, security considerations remains the most important agenda among the establishment in Tokyo in carving up a national security policy that seeks to ensure the country's peaceful existence in the volatile region.

As far as the Japanese defense establishment, politicians, security experts and media are concerned, their perception on the China threat toward their country's national security comes from the fact that the all-out Chinese expansionism in the region is negatively affecting the military, political and economic status quos enjoyed by Japan in past decades. Such unease is prevalent among the rhetoric circulated by national politicians with the likes of Shintaro Ishihara, Prime Minister Shinzo Abe and the defense bureaucracy. Overall, their arguments on the China threat toward Japan's

1 This research will not be possible if not for the generous University of Malaya's PPP research grant awarded to us for field study in Tokyo. Acknowledgements and appreciation have to be given to my interviewer, Vice-Admiral (ret) Hideaki Kaneda, Adjunt Fellow at the Japan Institute of International Affairs (JIIA) for his insightful comments relating to Japanese military security and views on China's military buildup.

2 Jiang Ye, "Will China be a "Threat" to its Neighbors and the World in the Twenty First Century?," Ritsumeikan Annual Review of International Studies Vol. 1, 2002, p 56. 
national security revolves around two trends, namely, China's military ascendancy and its non-military activities in the East China Sea. ${ }^{3}$ This article, therefore, aims to comprehend the two facets of China threat to Japan's national security from a third party perspective. Overall, the paper is divided into three sections. First, it examines China's present national security concerns in Northeast Asia that contributes to the country's expansionist agenda. In the following section, the paper seeks to expound two facets of China's expansionist threats, Beijing's military ascendancy and intensification of Chinese civilian and maritime enforcement activities in the contended East China Sea, in relation to Japan's national security considerations in the Northeastern Asian region. Finally, the paper concludes its empirical findings in relations to East Asian regional security cooperation.

\section{China's National Security Perceptions in the Region}

At present, China's national security perceptions derives from three fronts: maritime sovereignty, guarantees of access to sea lanes and resources vital for the nation's growing economic needs as well as perceived military encirclement led by the United States (US). Spurred by historical legacies of semi-colonial status as well as China's "century of humiliation", Beijing views its current rising national power as a means to reclaim the territories, be it sea or land, and the civilization greatness it once lost more than a century ago. In an apparent attempt to institutionalize such endeavor, the Territorial Sea and Contiguous Zone Law was enacted during the 24th Meeting of the Standing Committee of the National People's Congress (NPC) in 1992. With the passing of the law, China's "sovereignty" was extended beyond its current border to include Taiwan, the offshore islands of Diaoyu/Senkaku, Penghu/Pescadores, Dongsha/Pratas, Xisha/ Paracel, and Nansha/Spratly as well as their adjacent seas. ${ }^{4}$ Such a unilateral move has sown seeds for potential confrontation not just between Beijing (both regimes and the masses) and the claimant states such as Japan in the context of East China Sea, but also the US which backs its allies in these territorial disputes in order to restrain Beijing's expansionist endeavors. More importantly, the same law serves as the raison d'être for Chinese maritime and civilian activities in the contented seas, especially in the East China Sea and the Taiwan Straits.

Also, China is "held hostage" to the "Malacca dilemma" in which a country's economic fortune is greatly dependent on its access of sea lanes in Southeast Asia. As the US Commerce Department observed, China has surpassed the US as the world's largest trading nation in 2012. At the same time, Chinese skyrocketing oil consumption

3 Shintaro, Ishihara, "Chinese Threat is Axis Around Which US-Japan Relations Will Turn in the Future," Global Viewpoint, 10 August, 2001,<http:/ / www.digitalnpq.org/global_services/ global\%20viewpoint/10-08-01.html>, accessed 12 May, 2012; "LDP Candidates Take Tough Line Against China," Kyodo News, 18 September 2012, <http:/ /www.japantimes. co.jp/text/nn20120918b1.html>, accessed 19 September, 2012; and Ministry of Defense (MOD) Japan, Defense of Japan 2012, Tokyo: MOD Japan, 2012, <http:/ / www.mod.go.jp/e/ publ/w_paper/2012.html>, accessed September 1, 2012.

4 Allen Carson, Unifying China, Integrating with the World: Securing Chinese Sovereignty in the Reform Era (Singapore: NUS Press, 2008), p. 36; Samuel S. Kim, China, the United Nations and World Order, Princeton: Princeton University Press, 1979); and Sujit Dutta, "Securing the Sea Frontier: China's Pursuit of Sovereignty Claims in the South China Sea," Strategic Analysis 29, No. 2, April-June 2005, p 275. 
has reached nearly 60 per cent of world's share in $2006 .{ }^{5}$ Considering these situations, the Chinese government's moves to enlarge its stakes in the sea lanes of commerce (SLOCs) is bound to affect Japan's economic security as well since 90 per cent of the latter's Middle East oil shipments which passes through the Bashi Channel near Taiwa, ${ }^{6}$ adjacent to the East China Sea. Furthermore, Beijing's search for new oil, gas and fish resources in the region also pitts it against existing Japanese political sovereignty and economic interests in the region.

Following Obama administration's "pivot to Asia" policy since 2008, renowned military strategists in China such as Dai Xu, Ni Leixiong, Tang Xiaosong and Luo Yuan perceive the recent American air-sea battle plan, intensification of military drills with Japan and South Korea, sales of Patriot anti-missile defence system to Taiwan, involvements in the disputes of the East China Sea and South China Sea and engaging India militarily, as Washington's renewed efforts to form an East Asian version of NATO coalition against China's expansionist security agenda in the East Asian region. ${ }^{7}$ In the words of Dai, the present enlargement of Washington's strangulation of Beijing from the Pacific to the Indian Ocean is part of a grander plan of forming a crescent /C-shaped military encirclement against China's growing power. ${ }^{8}$ Within this context, the decades-old US-Japan military alliance remains a primary hurdle for Beijing and this has resulted in Beijing strategizing through military means.

\section{The Two Dimensions of China Threat to Japan's National Security}

\section{China's Military Ascendancy}

Presently, Beijing views military build-up as the most crucial strategy in altering the overall military balance in East Asia that is currently in favour of the US-Japan combined forces or the Japanese military in the East China Sea for. ${ }^{9}$ On one hand, for Tokyo, Chinese

5 “China Eclipses US as Biggest Trading Nation," Bloomberg, 11 February, 2013, <http:/ / www. bloomberg.com/news/2013-02-09/china-passes-u-s-to-become-the-world-s-biggesttrading-nation.html>, accessed 1 March, 2013; Shaofeng Chen, "China's Self-Extrication from the "Malacca Dilemma" and its Impact on ASEAN," International Journal of China Studies, Vol,1, No. 1, January 2010, pp 2-5.

6 Shaohua Hu, "Japan and the Cross-Taiwan Strait Conflict," Journal of Chinese Political Science, Vol. 11, No. 2, Fall 2006, p 90; Hisahiko Okazaki, "The Strategic Value of Taiwan" (paper presented for US-Japan-Taiwan Trilateral Strategic Dialogue, Tokyo, Japan, 2 March, 2003).

7 Xu Dai, "Dai Xu: Zhongguo ying gei meiguo weidu xingwei hua hongxian [Dai Xu: China Should Draw a Red Line against the US Encirclement Efforts]," Huanqiu Shibao [Global Times], 2 August, 2010, <http://opinion.huanqiu.com/roll/2010-08/977633.html>, accessed 2 May, 2012; Jize Qin and Xiaokun Li, "China Circled by Chain of US Anti-Missile Systems," China Daily, 22 February, 2010, <http://www.chinadaily.com.cn/world/2010-02/22/ content_9481548.htm>, accessed 2 May 2012; Chris Buckley, "PLA Researcher Says US Aims to Encircle China," Reuters, 28 November, 2011, <http://www.reuters.com/ article/2011/11/28/us-china-usa-pla-aidUSTRE7AR07Q20111128>, accessed 2 May, 2012.

8 Dai; D. S. Rajan, "China: US Accused of Strategically Encircling China," South Asia Analysis Group, 30 May, 2010, <http:/ / www.southasiaanalysis.org/papers39/paper3836.html>, accessed 2 May, 2012.

9 Institute of International Policy Studies (IIPS) Japan, A New Chapter in Japan-China Relations: Towards Co-existence and Co-development that Overcomes History, 23 April, 2008, pp 20-21, <http://www.iips.org/jcr/jcr-e.pdf>, accessed 20 July, 2012. 
military rise in the forms of military budget increase and modernization measures destabilizes the regional military security that is retained through US-Japan military ascendancy in East Asia and the Japanese military prowess in the East China Sea. On the other hand, the intensification of People's Liberation Army's (PLA) military activities in the seas surrounding Japan which is aimed at testing China's newly acquired naval and air A2/ AD capabilities and turning it into real offshore defense applications, challenges Tokyo's political legitimacy over its national boundaries and poses an immediate threat to the country's military security.

\section{Beijing's Defense Spending Increase and the Issue of Military Transparency}

The increase in China's defense spending and the issue of military transparency have sparked off one of the greatest concerns among countries in the Pacific Rim and more so its neighbour, Japan. While Tokyo had the upper hand in terms of military spending before 2003, this was not the case from 2005 onwards. As shown in Figure 1, Stockholm International Peace Research Institute (SIPRI) capped Beijing's military budget (based on current prices) at US\$ 40.01 billion in 2004. However, it skyrocketed to US\$ 188.46 billion in 2013 from US $\$ 46.29$ billion in $2005 .{ }^{10}$ This represents a 307.13 per cent increase within the 9-year period. Taking the amount China invested in its military as of 2013, this indicates that the economic powerhouse has become the world's second biggest military spender after the US, successfully taking the crucial spot away from Japan.

Despite Japan's efforts to introduce supplementary budget on top of its defense budget in 2013, Tokyo's overall defense budget (current prices) has been trailing behind China's military expenditure from the period of 2005 to 2013. In that 9-year period, Japan's defense spending increased by 8.75 per cent or 1.09 times. This is in stark contrast to China's 4.07 times increase of its military spending based on the latter's official figures. ${ }^{11}$ For Japanese foreign affairs official and security experts, Takashi Hoshiyama and Yoichi Sato, such a trend is likely to change the military balance in favor of both the US and Japan in the wider East Asia and Japan's military advantage specifically in the East China Sea. ${ }^{12}$ In both cases, Japan's security assurance relies heavily on these structures that have maintained peace and stability for the past two decades. China's escalating military spending, on the other hand, is poised to challenge that status.

\footnotetext{
10 Stockholm International Peace Research Institute (SIPRI), “The SIPRI Military Expenditure Database," < http://www.sipri.org/research/armaments/milex/milex_database/milex_ database>, accessed 25 July, 2014.

11 SIPRI Military Expenditure Database. In contrast to China's 2 to 2.1 per cent, Japan's military budget as a proportion of its GDP is 1 per cent for the 9-year period.

12 Takashi Hoshiyama, "Japan's Perspective on the Threat and Opportunity of China," in Towards Pax Sinica?: China's Rise and Transformation: Impacts and Implications, ed. Emile Yeoh Kok-Kheng, Kuala Lumpur: Institute of China Studies, 2009, p. 79; Yoichiro Sato, "Tango without Trust and Respect? Japan's Awkward Co-Prosperity with China in the Twenty-First Century," in The Rise of China and International Security: America and Asia Respond, ed. Kevin Jooney and Yoichiro Sato, Oxon: Routledge, 2009, p. 108.
} 
Figure 1 SIPRI's Comparison between China's and Japan's Official Military Expenditures (2003-2013)

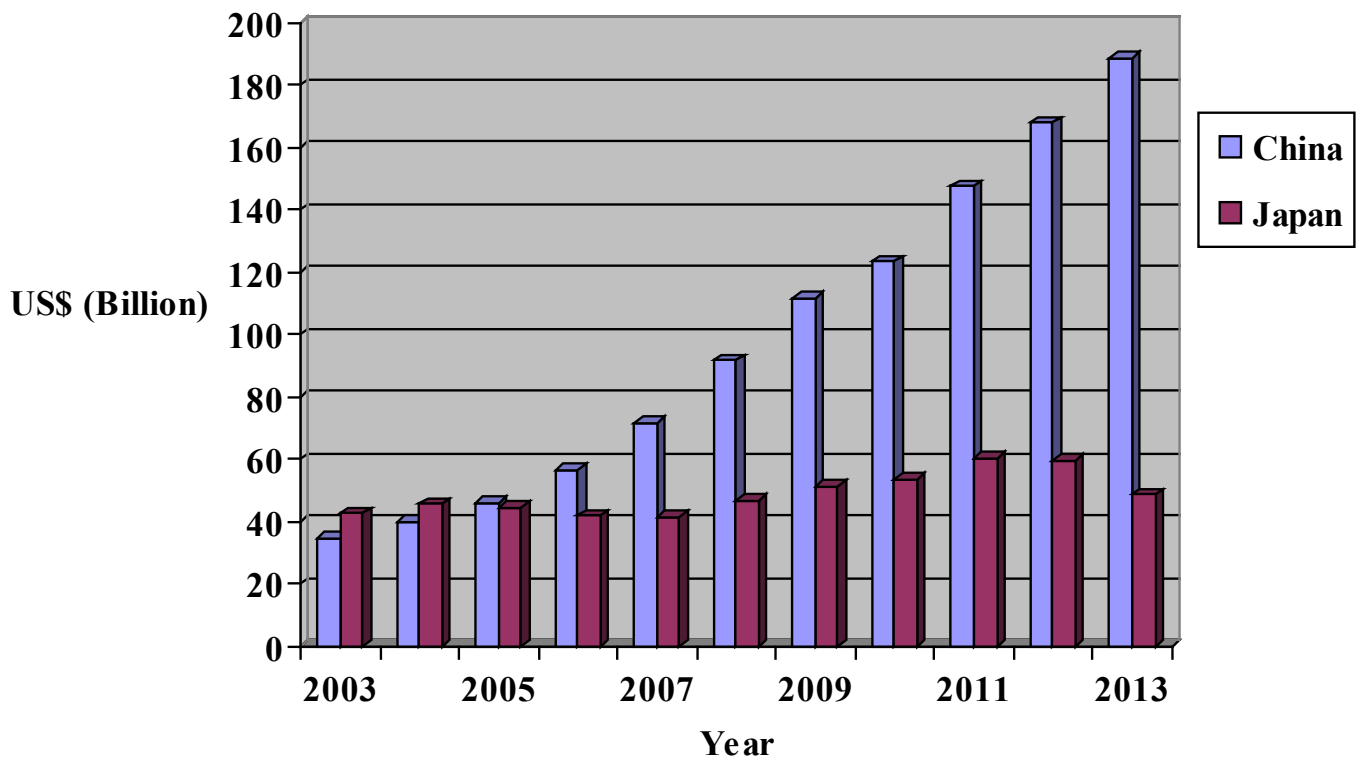

Source: SIPRI Military Expenditure Database, <http://milexdata.sipri.org/>, accessed 25 July, 2014.

Another critical concern of Tokyo is the lack of military transparency in China's defense budget. First, there is the question of validity and reliability of the military statistics provided by the Chinese government. In comparison with those obtained from numerous Chinese sources, SIPRI has found that there is a significant gap between official and actual defense expenditures for more than two decades. As in Figure 2, such gap has widened considerably every year since 2001 and the Swedish think tank forecasted that China's defense budget actually surpassed its RMB 800 billion or US\$ 127.04 billion mark in 2010. Based on SIPRI's estimates, the real budget for that year alone was at least 50.94 per cent or 1.51 times higher than Beijing's announced budget of US\$ 84.17 billion. In a more extended period from 2001 to 2010, the differences would translate into a relative rise of at least 151 per cent for the ten years' period. ${ }^{13}$ These findings invariably meant that China's overall size of military spending for the first decade of the $21^{\text {st }}$ century is actually 1.5 times larger than the one reported by the central government.

13 Brian Yeh and Phillip C. Saunders, China's 2012 Defense Budget: Steady as She Goes," Institute for National Strategic Studies (INSS) Dynamic Dialogue, 26 March, 2012, <http://inssblog. wordpress.com/>, accessed 22 April, 2012. 
Figure 2 Comparison between China's Official Defense Expenditures and SIPRI Estimates

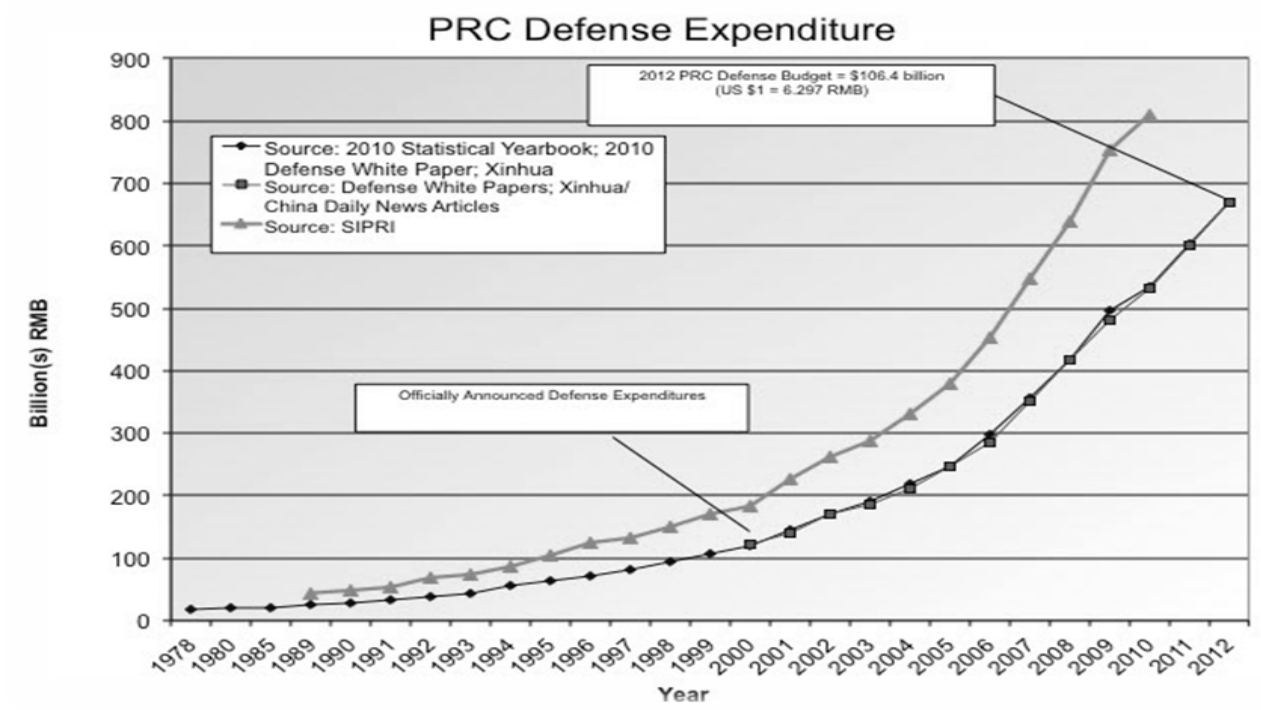

Source: Quoted from Brian Yeh and Phillip C. Saunders, China's 2012 Defense Budget: Steady As She Goes," Institute for National Strategic Studies (INSS) Dynamic Dialogue, March 26, 2012, <http://inssblog.wordpress. com>, accessed 22 April 2012.

Part of the Tokyo's skepticism about China's under-reported defense budget stems from Beijing's failure to include the costs of equipment procurements and its research and development expenditures in its white paper, the China's National Defense, published once in every two years. ${ }^{14}$ Unlike Japan's defense release, the Chinese document showed only the total defense budget, its share in the GDP and the general funding allocations in the areas of personnel, training, maintenance and equipment. Moreover, China had repeatedly submitted its military report to the UN in simplified and not the standardized form as commonly practiced by countries with high military transparency. ${ }^{15}$ It was only after the October 2009 great military parade to commemorate the $60^{\text {th }}$ anniversary of the founding of the PRC that a number of highly modernized PLA equipment were publicly displayed such as airborne and amphibious combat vehicles, satellite communications, unmanned reconnaissance aircraft and inter-continental ballistic missiles (ICBMs), DF- 31A. ${ }^{16}$

14 Ministry of Defense (MOD) Japan, Defense of Japan 2011, Tokyo: MOD Japan, 2011, p 75, <http:/ / www.mod.go.jp/e/publ/w_paper/2011.html >, accessed 15 April, 2012.

15 For information about China's structure of defense budget and criticism, see China's National Defense in 2010, Beijing: Information Office of the State Council, 2011, <http:/ / china.org.cn/ government/whitepaper/node_7114675.htm>, accessed 12 June, 2011; US Department of Defense (DOD), Annual Report to Congress: Military and Security Developments Involving the People's Republic of China 2010, Washington DC: US DOD, 2010, p 43, <http:/ / www.defense. gov/pubs/pdfs/2010_CMPR_Final.pdf>, accessed 4 June, 2011.

16 National Institute for Defense Studies (NIDS), NIDS China Security Report 2011 (Tokyo: NIDS, 2012), p 2, <http://www.nids.go.jp/english/publication/chinareport/pdf/ china_report_EN_4C_A01.pdf $>$, accessed 3 July, 2012. 
As a concerned neighbor, Tokyo has repeatedly urged Beijing to be more open in reporting its military budget and developments in line with the requirements highlighted by the then Japanese defense minister, Toshimi Kitazawa, in November 2009. A total of four demands were suggested which included having China provide a detailed list of arms and equipment, procurement targets and major equipment, formation and deployment of major units and breakdowns of the total defense budget. ${ }^{17}$ Unfortunately, China has yet to comply, prompting fears among Japanese leaders that the camouflage of Chinese military capabilities may prove to be difficult for others to gauge their real capacities. As the then foreign minister Maehara put it, the transparency problem also affects the present military balance in the region and thus, disrupts Japanese national security that is maintained by the US-Japan security alliance and Japan's military prowess. ${ }^{18}$

\section{Modernization of the People's Liberation Armed (PLA) Forces for Offshore Active Defense Strategy}

Adapted from Admiral Liu Huaqing's concept in the 1980s, China's "offshore active defense" strategy is based on two island chains that demarcates Beijing's defense interests in the near and far seas: the first series of islands includes the Aleutians, the Kurile Islands, Japan's south-western islands including Okinawa, Taiwan, the Philippines, Vietnam and East Malaysia while the second string of islands runs from the Bonin Islands (near Japan) in the north to the Marianas, Guam, Palau and Irian Jaya in the south. ${ }^{19}$ In the first and second phases of the strategy, the PLA is to wring control of the seas within the first and second island chains against the projection power (military presence and activities) of the US-Japan/Japanese forces in East Asia. To solve the current asymmetrical military balance of power that favours the US-Japan forces, the acquisition of modern, targeted "anti-access/area-denial" (A2/AD) capabilities are vital to China's successive deterrence. In tactical terms, A2 involves the deployment of these capabilities to deter the enemy forces (in this case, US-Japan/Japanese) from entering and employing force in the foreign theatre/global commons such as Yellow Sea, and East China Sea; while AD is a form of military denial against enemies' successful armed operations in the contingency areas such as the Taiwan Straits, through ballistic missiles, aircrafts, air defense systems, and mines. ${ }^{20}$

17 MOD Japan, "Meeting of Defense Ministers of Japan and China," Japan Defense Focus no. 16, January 2010, p 2, <http://www.mod.go.jp/e/jdf/pdf/jdf_no16.pdf>, accessed 12 June, 2010.

18 Seiji Maehara, "Opening a New Horizon in the Asia Pacific," Foreign Policy Speech at the Center for Strategic and International Studies, Washington DC, 26 January, 2011, <http://www.mofa.go.jp/region/n-america/us/juk_1101/speech1101.html>, accessed 13 February 2011.

19 Huaqing Liu, Liu Huaqing huiyilu [The Memoirs of Liu Huaqing], Beijing: PLA Press, 2004, p 434-7, Sina.com, <http:/ / ishare.iask.sina.com.cn/f/24577271.html>, accessed 23 May, 2012; Michishita Narushige, "The Future of Sino-Japanese Competition at Sea," Nippon.com, 23 March 2012, <http://nippon.com/en/in-depth/a00504/>, accessed 20 May 2012.

20 Nathan Freier, "The Emerging Anti-Access and Area-Denial Challenge," Center for Strategic and International Studies (CSIS), 17 May 2012, <http://csis.org/publication/emerginganti-accessarea-denial-challenge>, accessed 12 June 2012. 
At this point, clarifications have to be made regarding the PLA's newly acquired power projection capabilities, namely, Liaoning aircraft carrier, airborne warning and control system (AWACS)-planes, long-range unmanned aerial vehicles (UAVs), Hong-10 (H-10) bombers and Type 081 model of landing helicopter dock (LHD). That Japan's national security is affected by the Chinese A2/ AD capabilities within the first and second island chains rather than Beijing's power projections measures means that these capabilities are way beyond the scope of discussions for this paper. Somewhat different than the two A2/AD phases, these instruments are pursued with the aim of protecting China's security interests beyond the second island chain in the Pacific (as stipulated within Liu Huaqing's third phase offshore defense strategy $)^{21}$ and in which Beijing would depend on to compete with the US and not Japan, for military primacy in the region.

In terms of naval A2/ AD capabilities, for the past ten years, the PLA Navy (PLAN) has continued the commission of new destroyers and frigates for air defense and antiship missile capabilities as part of the two island chains plan. ${ }^{22}$ As the Japanese defense circle views it, top of the new Luyan-II and Luzhou-II destroyers with longer-range surface-to-air and anti-ship missiles and larger phase radar, ${ }^{23}$ large Jiangkai II stealth frigates with intermediate-range HHQ-16 surface-to-air missiles, SAMs, may be massproduced $^{24}$ to support the Chinese naval defense of the country's surrounding seas, especially in the East China Sea and the Taiwan Straits. Inclusive of the new Houbei-class (Type 022) patrol missile boats equipped with YJ-83 anti-ship cruise missiles (ASCMs) are deployed for close coastal defense, the PLAN has altogether modernized 25 per cent of its surface combatants as of 2008-another stark increase from a little more than 5 per cent in $2004 .^{25}$

Meanwhile, China's modernization of undersea combatants is the largest in the world. The PLAN appeared to concentrate all its efforts in building a new submarine fleet with anti-surface warfare (ASuW) capabilities for navigation and operation in the seas within the two island chains. The existing submarine fleet has been transformed into one that possesses stealthy and ASCM capabilities and thus, able to roam free undersea and mount sneak offensives against the enemies' carrier strike fleets in coordination with ground ballistic attacks. By 2008, the PLAN had virtually transformed about 50 per cent of its 60 submarines into advanced versions, thus a five-fold increase from roughly 9 per cent in 2004. According to the US Congressional Research Service, the current PLAN's commissioning rate of 2.6 submarines a year may eventually steer China to possess up to 79 submarines in the coming years. ${ }^{26}$

Apart from the existing twelve Russian Kilo-class (Type 636) diesel-attack submarines equipped with supersonic SS-N-27B/Sizzler anti-ship cruise missile and quieting technology that may threaten the Aegis missile defense system on both the

${ }^{21}$ Huaqing Liu, p 437.

22 David Bennettt, "An Analysis of the China's Offshore Active Defense and the People's Liberation Army Navy," Global Security Studies, Vol. 1, No. 1,2010, p 130.

23 NIDS China Security Report, p 35.

24 NIDS China Security Report, p 35.

25 Bennett, p. 130; Ronald O' Rourke, China Naval Modernization: Implications for US Navy Capabilities: Background and Issues for Congress, Washington, DC: Congressional Research Service, 2011, p 26, <http://www.fas.org/sgp/crs/row/RL33153.pdf >, 20 accessed June 2012.

26 Ronald O' Rourke, pp 19-20. 
American and Japanese naval vessels and the recent joint-construction of four stealthy Lada-class submarines, ${ }^{27}$ the PLAN has deployed its indigenous-made submarines to complement the Kilos' weaknesses. According to Japan's NIDS China Security Report, following the launching of the non-nuclear powered Yuan submarine with longer undersea operational sustainability, ${ }^{28}$ the Chinese Shipbuilding Industry Corporation has revealed yet another advanced variant of Yuan-class armed with C-705 ASCM, in September 2010. ${ }^{29}$ Then, the PLA has also deployed the Shang-class submarines in recent years. Being fast with good tracking ability and furnished with YJ-82 ASC, these nuclear-powered submarines (SSN) could partner with the Yuans and the Songs to strike against the enemies' navies at near seas after having the latter's air and missile defenses decapitated to a significant degree ${ }^{30}$ by the ground-launched anti-ship ballistic missiles (ASBMs). In the near future, Japanese senior defense figures such as Hideaki Kaneda speculate that the Chinese will replace the Shangs with newer variants of SSNs-a prediction that was confirmed by the US Department of Defense (DOD) on China's new Type-095 (Shang-class successor) models, which will be operational ready in 2015. ${ }^{31}$

For aerial A2/AD, the PLA Air Force (PLAAF) has already started replacing the older fighters with newer fourth-generation planes. Again, Japan's NIDS stated that in the first ten-year period of the twenty-first century, the share of fourth generation fighters to overall number of planes have increased from 3.7 per cent in 2000 to 10 per cent in 2005 and to around 28 per cent in $2010 .{ }^{32}$ As one of the backbones of the PLAAF, the Su-30MKK2s (an advanced variant of Russian Su-30) are presently armed with Kh-31 long-range supersonic anti-ship missiles (ASMs), Kh-31P anti-radiation missile, TV-guided bombs and possesses remarkable combat radius of 1,600 $\mathrm{km}$ without any refueling. ${ }^{33}$ With multiple in-flight refueling from IL-78 aerial refueling tanker, it would be able to spend considerable time "patrolling" and "safeguarding" the first two island chains from enemies' entries. ${ }^{34}$ Moreover, the latest purchase of 48 highlyadvanced Su-35BMs, the introduction of high-tech fifth-generation fighters by 2019 such as Jian-20s (J-20s) and the plan for sixth-generation fighters will also assume A2/

27 Eric A. McVadon, “China's Maturing Navy,” Naval War College Review, Vol. 59. No. 2, 2006, p 97; "Zhonger qianshu jué junshou hetong gou zhanji qianting [China-Russia Signs Massive Arms Deal on Fighter Jets and Submarines]," BBC Chinese Web, 25 March, 2013, < http:/ / www.bbc. co.uk/zhongwen/simp/china/2013/03/130325_china_russia_military.shtml>, accessed 26 March 2013.

28 NIDS China Security Report, p 34.

29 Ted Parsons, "Mystery Chinese SSK fuels Asia's submarine race," Jane Defence Weekly, 21 September 2010, <http://www.defence.pk/forums/chinese-defence/73561-mysterychinese-ssk-fuels-asias-submarine-race.html>, accessed 2 June 2011.

$30 \quad$ NIDS China Security Report, p 34; McVadon, p 97.

31 USDOD, Annual Report to Congress: Military and Security Developments Involving the People's Republic of China 2011, Washington DC: US DOD, 2011, p. 4, <http:/ / www.defense.gov/ pubs/pdfs/2011_CMPR_Final.pdf>, accessed May 2, 2012; and Vice-Admiral (ret) Hideaki Kaneda, interview by first author, Japan Institute of International Affairs (JIIA), Tokyo, 22 September, 2011.

32 NIDS China Security Report, p 36.

33 SinoDefence.com, "Su-30MKK Multirole Fighter Aircraft," sinodefence.com, <http:/ / www. sinodefence.com/airforce/fighter/su30.asp>, accessed 7 December , 2011.

34 SinoDefence.com, 
$\mathrm{AD}$ responsibilities, especially in the contested areas ${ }^{35}$ within the second island chain. Once deployed together with other Jian fourth-generation fighters (J-10s and J-11s) and bomber, Hong-6Gs (H-6Gs), the whole air fleet would provide effective air support and protection to the Chinese naval fleet in their sea blockade operations. All these increase the aerial risks of the US and Japanese naval and air forces in the region.

The most successful weapon, however, remains to be China's ground-launched ASBMs, Dong Feng 21-Ds (DF-21Ds or CSS-5 Mod-4s), which targets primarily the US-Japan projection power in the Pacific and East China Sea: the American aircraft carriers and the Japanese helicopter destroyers. Modified from the medium-range ballistic missiles (MRBMs), these missiles could be launched from coastal areas in China to infiltrate the defense of the highly mobile US aircraft carrier around 1,500 km away from the initiation ground..$^{36}$ This, in effect, exposes the American and Japanese surface naval ships operating in the first island chain to the PLA Second Artillery's offensive power and thus, ensures the safety of Chinese territories. Furthermore, in the case of a reunification war in the Taiwan Straits, the PLA could bank on these missiles to prevent the entry of the US-Japan/Japanese military forces in the near seas to negatively affect the latter's successful presence and military conducts through effective resistance in the Taiwan Straits. This would then bestow upon the PLA much needed time and space to mount effective offensives against the military targets in Taiwan. Hence, the introduction of these new missiles signifies the end of safe access of the US-Japan/Japanese naval forces to the East China Sea and the Yellow Sea (or even the South China Sea) which they have enjoyed for decades as well as the allied forces' successful intervention during any contingencies in Taiwan.

While these "aircraft carrier killers" have obtained initial operational capability (IOC) as claimed by former commander of the US Pacific Command, Admiral Robert Willard, ${ }^{37}$ there is also speculation among experts that the Chinese military may contemplate multiple warheads to greatly boost the offensive power of the DF-21Ds in the near future as opposed to the present single warhead within a single missile known as multiple independently targetable re-entry vehicle (MIRV) capability. ${ }^{38}$ Besides, any USJapan/Japanese military deliberation against China would have to overcome Beijing's

35 "Zhonger qianshu jué junshou hetong gou zhanji qianting," BBC Chinese Web; Jingyin Deng, "New Generation of Fighter Jets on Horizon," Global Times, 10 November 2009, <http:// military.globaltimes.cn/china/2011-04/483864.html>, accessed 25 May 2010; Jens Kastner, "Stealth Fighter Sneaks Up on Taiwan," Asia Times, 21 January 2011, <http:/ / www.atimes. com/atimes/China/MA21Ad02.html>, accessed August 25, 2011; and "6th-Gen Chinese Fighter before 2030 Highly Unlikely Says Russian Analyst," Want China Times, 17 December 2012, <http:/ / www.wantchinatimes.com/news-subclass-cnt.aspx?id=20121217000123\&c id=1101>, accessed 20 December 2012.

36 Eric Talmadge, "Pacific Power May Shift with China's Missile," Associated Press, 6 August 2010, <http://www.washingtontimes.com/news/2010/aug/6/pacific-power-may-shiftwith-chinese-missile/>, accessed 7 May 2011.

37 Yoichi Kato, "US Commander Says China Aims to be a 'Global Military' Power," Asahi Shimbun, December 28, 2010, <http:/ / www.china-defense-mashup.com>, accessed 6 May 2011.

38 Harry Kazianis, “China's Anti-Access Missile," The Diplomat, 8 November 2011, <http:/ / thediplomat.com/flashpoints-blog/2011/11/18/chinaa-anti-access-missile/>, accessed 23 February 2012. 
variety of missiles: the 7,400 km-range Ju Lang-2 (JL-2) submarine-launched ballistic missiles (SLBMs) operated by the Jin-class (Type 094) submarines, ${ }^{39}$ conventional and nuclear DF-21A/B/C MRBMs and 1,500 km-range Dong Hai-10 (DH-10) land-attack cruise missiles (LACMs) on board the vessels and aircrafts as well as the much forsaken Hong Qi-9 (HQ-9) surface-to-air missiles (SAMs). Once used in coordination with the DF-21Ds' attacks on naval ships, these missiles could strike on the enemies' land-based and air targets ${ }^{40}$ in the areas between the first and second island chains.

In line with China's military "informatization" (unified command, control communications, computers, intelligence, surveillance and reconnaissance, C4ISR) designed to be achieved by 2020, the PLA has been upgrading its information and space capabilities to better support its A2/ AD capabilities on the ground, air and sea. In recent years, Chinese cyber attacks on the Japanese governmental or defense-related sites have been attempted annually. ${ }^{41}$ From September 17 to September 18, 2011, Japanese police authority revealed that the sites of the Cabinet Office, National Personnel Authority, governmental videos distribution service and the computer system of Japan's largest defense contractor, Mitsubishi Heavy Industries Limited, were reportedly hacked by unverified sources in China as part of the "commemoration of the Manchurian Incident in 1931". ${ }^{42}$ The success of these cyber attacks give indications that the Chinese military might has already acquired the know-how of computer network attacks that have been operating in the same way as the site attacks. In a real military situation, the US DOD deems that the PLA could skillfully utilize these computer network attacks together with electronic counter-measures to hinder the US-Japan/Japanese forces' data access for successful accomplishment of military operations in the seas within the first and second island chains. ${ }^{43}$

On the other hand, China has vigorously pushed for progress in new space and counter-space capabilities in tandem with its future military informatization plan. After the controversial anti-satellite (ASAT) test in January 2007 that drew heavy criticism

39 China Naval Modernization: Implications for US Navy Capabilities: Background and Issues for Congress, p. 16; and Annual Report to Congress: Military and Security Developments Involving China 2011, pp 34-5.

40 “The Other China Missile Threat," The Diplomat, 11 May 2012, http://thediplomat.com/ flashpoints-blog/2012/05/11/the-other-china-missile-threat/>, accessed 2 June 2012; "FD2000/HQ-9 SAM - China's Strategic 'Game Changer', " Air Power Australia, December 6, 2009, <http:/ / www.ausairpower.net/APA-NOTAM-061209-1.html>, accessed 2 June 2012; MOD Japan, Defense of Japan 2011, p 78; and NIDS Japan, NIDS China Security Report, p 37.

41 Starting 2010 onwards, China's cyber attacks in the world are mentioned annually in the United States' Annual Report to Congress on Military and Security Developments Involving China.

42 Julian Ryall, "Japan Targeted by Cyber Attacks from China," The Telegraph, 20 September 2011, <http://www.telegraph.co.uk/news/worldnews/asia/japan/8775635/Japantargeted-by-cyber-attacks-from-China.html>, assessed 13 March 2012; Rachel Rickard Strauss and Rob Waugh, "Missile and Submarine Secrets 'May Have Been Stolen' in Cyber Attack on Japanese Defence Firm," Daily Mail, 19 September 2011, <http:/ / www.dailymail. co.uk/sciencetech/article-2039220/Mitsubishi-Heavy-cyber-attack-Japans-defencesecrets-stolen.html>, assessed March 13, 2012; and "Japan Blames China for Concerted Cyber Attacks," The Drum, 20 September 2011, <http:/ / www.thedrum.co.uk/news/2011/09/20/ japan-blames-china-concerted-cyber-attacks>, assessed 13 March 2012.

43 Annual Report to Congress: Military and Security Developments Involving China 2010, p 7 and 37. 
from the then Japanese Chief Cabinet Secretary, Yasuhisa Shiozaki, on China's exact intention, the PLA appeared to have been testing the new Dong Neng-2 (DN-2) ASAT missile that targets satellites in the higher altitude of $20,000 \mathrm{~km}$ above the earth's surface ${ }^{44}$ This effectively places the US and Japanese military satellites which are crucial in the combined forces' military communications and missile guidance on earth, into the Chinese sphere of attacks. Simultaneously, Chinese deployment of indigenous-made satellites into space, installation of its own Beidou-2 positioning system, dispatch of astronauts annually for setting up a permanent space station by 2020, and the planned establishment of an independent "air-space battle" military unit, ${ }^{45}$ has indicated that Beijing is ready to compete with the US and Japan for dominance in space. At this stage, it is expected that such efforts will greatly boost the PLA's A2/AD measures on the ground and in the waters within the first two island chains.

\section{Intensification of Chinese Military Activities in the Seas Surrounding Japan}

In his statement made during a military inspection parade in Tokyo in 2010, the then Japanese prime minister, Naoto Kan again flared up China's intensification of military activities in the waters surrounding Japan as another important development that posed an immediate threat to the country's military security. ${ }^{46}$ With China is eager to test its newly acquired naval and air capabilities for its offshore defense strategy, it is expected that the PLA will depart from its sporadic naval conducts in the early years of the twenty-first century and will consistently deploy its naval vessels and aircrafts for training and information-gathering missions in the seas within the first and second island chains as well as beyond. In the words of Sugio Takahashi, a high-rank defense ministry official and the NIDS senior fellow, China's increasing threats in the forms of military and non-military activities surrounding Japan, are as serious as the A2/AD capabilities to Tokyo's national security. ${ }^{47}$ In this context, the activities of the Chinese naval and air combatants have amounted to what Tokyo views as more than a military threat per se but also a risk to its political legitimacy over the claimed seas and airspaces.

In terms of the PLAN's naval activities, three changes have been noted in recent years. First, the Chinese naval activities are in an increasing trend with as minimum

44 Richard Spencer, "Chinese Missile Destroys Satellite in Space," The Telegraph, 19 January 2007, <http://www.telegraph.co.uk/news/worldnews/1539948/Chinese-missiledestroys-satellite-in-space.html>, accessed 23 January 2011; and China's Anti-Satellite Test, Strategic Threat to the US?, Global Times, January 6, 2013, < http:/ / www.globaltimes.cn/ content/753998.shtml>, accessed 11 January 2013.

45 Annual Report to Congress: Military and Security Developments Involving China 2011, p 35-7; "Rimei cheng zhongguo jundui yu gao kong tian yiti zhan [Japanese Media Claims China Engaging in "Air-Space Battle" to Counter US-Japan]," Huanqiu Wang [Global Network], 17 November 2012, <http:/ / mil.news.sina.com.cn/2012-11-17/1032707015.html>, accessed 20 November 2012.

46 “Japan Facets 'More Severe' Security Situation," Agence France-Presse (AFP), October 24, 2010, <http://www.channelnewsasia.com/stories/afp_asiapacific/view/1089065/1/.html>, accessed 23 July 2011.

47 Sugio Takahashi, "Counter Ä2/AD in Japan-US Defense Cooperation: Toward Allied Áir-Sea Battle," Futuregram 12-003, 18 April 2012, <http:/ / project2049.net/documents/ counter_a2ad_defense_cooperation_takahashi.pdf $>$, accessed 13 November 2012. 
as one sighting is recorded each year since 2008. Up to 2013, at least eleven cases were reported, the climax of which four sightings were noted just in 2010 alone. Second, the PLAN's operational area has also broadened to include Japanese territorial waters which are frequently used as passageways for eventual military drills in China's near seas and international waters. Apart from having its Luzhou-class and Sovremenny-class destroyers navigating unreservedly through the Japanese waters between Okinawa and Miyako islands in November 2008, March 2010, July 2010 and June 2011, the Chinese naval fleets were seen breaking their traditional routes: in October 2008, the Chinese warships passed through Tsugaru Strait (between Honshu and Hokkaido islands) for the first time after encircling the Japanese waters in the north; and in June 2009, five PLAN's naval vessels successively sailed through Nansei islands to the waters off the northeast coast of Okinotori Island.48 In April 2012, the Chinese naval ships passed through another new route, the Osamu Strait-another indication that the PLAN is diversifying its activities in the seas surrounding Japan. ${ }^{49}$

Also, there appeared to be bolder actions from Chinese naval helicopters in confronting the Japanese MSDF vessels after the former was discovered in the Japaneseclaimed territorial waters. In early and end of April 2010, two cases where the PLAN helicopters ignored orders from its main fleets and flew extremely close to the Japanese MSDF destroyers, Suzunami and Asayuki, near Okinawa Island, as reported by the Ministry of Defense (MOD). Later, in March 2011, another case was also reported near the contested Chunxiao/Shirakaba gas field in East China Sea. The recent event occurred in January 2013, Chinese naval ships successfully radar-locked both a Japanese destroyer and the helicopter above the destroyer ${ }^{50}$ - a move that seriously alarmed the Japanese defense establishment.

As for the growing Chinese air reconnaissance activities, two worrying trends have been observed for the past few years. As in the figures revealed by the MOD Japan, the number of the country's jet scramble cases have been on an increasing trend from 2007 to 2011. The number of deployment of the Japanese Air Self-Defense Forces (ASDF) fighter jets in response to the PLAAF aircrafts' activities in the Japanese nearby airspaces, swelled from 43 to 156 times, thus representing more than a three-fold increase for the five-year period. The year 2011 had so far, recorded the highest numbers of ASDF's air scrambles in response to the Chinese aircrafts, occupying 36.71 per cent of the total air deployment. ${ }^{51}$ That said, the Chinese aircrafts have also widened their reconnaissance fly-ins to airspaces which the Japanese government considered as their own jurisdictions in the East China Sea. Following the Senkaku/Diaoyu Islands spat between the two countries in September 2010, China has abandoned its cautious policy in the East China

48 Defense of Japan 2011, pp 82-3; NIDS China Security Report, pp 15-6.

49 MOD Japan, Defense of Japan 2013, Tokyo: MOD Japan, 2013, p 39, <http://www.mod. go.jp/e/publ/w_paper/2013.html>, accessed 15 November 2013.

50 "Chinese Chopper 'Ignored Orders' / Insubordination within Navy Could Heighten Possibility of Accidents," Yomiuri Shimbun, 27 April 2010, <http:/ / www.sinodefenseforum.com/navy/ china-naval-drills-east-china-sea-2-5006.html>, accessed February 12, 2012; "China Copter Buzzes MSDF Warship," Kyodo News, 9 March 2011, <http:/ / www.japantimes.co.jp/text/ nn20110309f3.html>, accessed 20 May 2011; and Defense of Japan 2013, p 39.

51 "SDF Jets Scramble to Meet Chinese Planesa Record 156 Times," Asahi Shimbun, 26 April 2012, <http://ajw.asahi.com/article/behind_news/social_affairs/AJ201204260056>, accessed 8 May 2012. 
Sea and openly asserted its sovereignty rights in the disputed East China Sea by having its aircrafts making more entries into Japanese-designated Air Defense Identification Zone (ADIZ) and median line between the two nations. ${ }^{52}$ Several cases have been reported ever since and these include: the PLA's Jianjiji Hongzhaji-7 (JH-7) bomber flying over the Japanese-claimed ADIZ and median line in October 2010 and boldly approaching the ASDF aircraft without fear of being detected; Chinese maritime patrol aircraft, Yunshuji-8X (Y-8X), entering the ADIZ for reconnaissance mission on the Keen Sword joint military drill between US and Japan in December the same year; and two Chinese aircrafts flew across the median line into the airspace close to the contended Senkaku/Diaoyu Islands in March 2011..$^{53}$ Such trends is expected to escalate further following China's announcement of its own ADIZ in November 2013. ${ }^{54}$

\section{Escalation of Chinese Civilian and Maritime Enforcement Activities in the Disputed East China Sea Area}

Apart from the military threat, Chinese civilian and law enforcement efforts have also become more pronounced, so much so that they have developed into a significant nonmilitary threat to Japan's national security. For the past twelve years, there has been an absence of a provision within the 1997 bilateral fisheries accord that regulates fishing activities of both Japanese and Chinese fishermen in the East China Sea..$^{55}$ The issue of frequent encroachments of fishermen from both sides and claiming territorial waters has been conveniently shelved in Japan-China negotiations in subsequent years. ${ }^{56}$ Both authorities have exercised strict restraint in handling the territorial incursion problem for fear of affecting the overall bilateral relations, up until the Chinese trawler-Japan Coast Guard (JCG) patrol boat collision incident in September 2010. Unlike past cases, the episode saw the Chinese trawler's captain being detained by the JCG. ${ }^{57}$ The release of the Chinese captain two weeks later following Beijing's pressure on the then Naoto Kan administration has somehow emboldened other Chinese fishermen to continue their fishing activities near the Japanese-declared median line.

Besides, there is an upward shot of Chinese deep sea fishing vessels and catch yield in recent years. Though there is no final figure of the number of Chinese fishing boats

52 ADIZ is not similar to territorial airspace as any jet flying past the zone does not constitute a violation of territorial integrity. However, for aircrafts of other countries to fly through the zone, it is required that the relevant authorities notify the country which commands the ADIZ.

53 Yoichi Kato, "China Ratcheting Up Pressure in the Air," Asahi Shimbun, 28 December 2010; "China's Defense Buildup Lacking in Transparency," Yomiuri Shimbun, 6 March 2011, <http:/ / www.yomiuri.co.jp/dy/editorial/T110305003674.htm>, accessed 16 March 2011.

54 "China's New Air Defense Zone Sparks Backlash from Tokyo, Seoul," Asahi Shimbun, 25 November 2013, <http://ajw.asahi.com/article/asia/AJ201311250076>, accessed 26 November 2013).

55 Sakai Tanaka, "Rekindling China-Japan Conflict: The Senkaku/Diaoyutai Islands Clash," The Asia-Pacific Journal: Japan Focus, 27 September 2010, <http:/ / www.japanfocus.org/-tanakasakai/3418>, accessed 23 May 2012.

56 Sakai Tanaka, 27 September 2010.

57 "JCG Arrests Chinese Capt. over Collision," Yomiuri Shimbun, 9 September 2010, <http:/ / www.yomiuri.co.jp/dy/national/T100908005026.htm>, accessed 15 September 2010. 
operating around the contended Sino-Japanese EEZs, the figures disclosed in the China Fishery Statistical Yearbook 2011 provides an excellent clue about the country's recent fishing trend in the disputed waters. For the four provinces of Fujian, Jiangsu, Zhejiang and Shanghai that border the East China Sea, the total number of motor ships usable for high seas (inclusive of the EEZs) fishing has upped to 590 in 2010, that is, an increase of 20.16 per cent from 491 in 2007..$^{58}$ The fact that more of such boats are produced for the last two years meant that more and more Chinese fishermen are willing to sail to deep sea for fishing purposes.

Moreover, the East China Sea yields the largest volume of China's fishing output in 2010. Despite Beijing's summer fishing moratorium placed on the Chinese fishermen starting from 1999, there was a surprisingly 10.4 per cent increase in total catch in East China Sea from 4,183,807 tons in 2007 to 4,618,934 tons in 2010.59 This explains why in just one day in October 2011, the MSDF surveillance aircraft managed to monitor as much as 200 Chinese fishing vessels operating in the waters nearby the Senkaku Islands chain. ${ }^{60}$ Then, in another recent development, there was a joint call among various Chinese maritime authorities for the inclusion of the transformation plan of Chinese fishing boats which among others, outlines the technological and capacity upgrading measures of these vessels, into the central government's national strategic priority in March 2012. Should the plan be adopted by the Chinese leadership, we could expect huge numbers of new Chinese civilian ships sailing to Japan-claimed EEZ for fishing activities. ${ }^{61}$ Given all these encouraging developments, the chances of Chinese fishermen undertaking fishing voyages to the Japanese-claimed seas in the near future have significantly increased. These audacious attempts are likely to threaten both Japan's political legitimacy and economic interests in waters disputed by China but administered by Japan.

On the other hand, in recent years, the nationalist civilian groups of the "Protection of Diaoyu Islands Movement" (baodiao yundong) from Hong Kong, China and Taiwan have made more landing attempts on the disputed Senkaku Islands to plant Chinese and Taiwanese flags. Despite the tragic island-landing crisis that resulted in the death of David Chan, a Hong Kong activist, in 1996 and the arrest of seven anti-Japanese activists for illegal entry into the islands, such efforts, aimed to re-affirm the Chinese sovereignty over the islets, have continued albeit intermittently. Four more cases were reported in October 2006, June 2008 and June 2011, all ended in failure due to blockading

58 Ministry of Agriculture Bureau of Fisheries China, Zhongguo Yuye Tongji Nianjian [China Fisheries Statistical Yearbook 2011], Beijing: China Agricultural Press, 2011, p 77, Docin.com, <http://www.docin.com/d-340800.html>, accessed 12 August 2012; and MOA Bureau of Fisheries China, Zhongguo Yuye Nianjian [China Fisheries Yearbook 2008] (Beijing: China Agricultural Press, 2008), Docin.com, <http:/ / www.docin.com/p-384482285.html>, accessed 12 August 2012.

59 Lyle J. Goldstein, "Strategic Implications of Chinese Fisheries Development," China Brief, Vol. 9, No. 16, August 5, 2009, p 11; Zhongguo Yuye Tongji Nianjian [China Fisheries Statistical Yearbook 2011], p 46; Zhongguo Yuye Nianjian [China Fisheries Yearbook 2008].

${ }^{60}$ Takashi Watanabe, "MSDF Keeps Eye in the Sky over Senkaku Islands," Asahi Shimbun, 15 October 2011.

61 "Zhuanjia jianyi jiang woguo haiyang yuchuan zhuangbei jishu fazhan shang sheng wei guojia zhanlue [Experts propose the inclusion of our fishing ships' equipments and technological developments into the national strategy]," Zhongguo Wang [China Web], 22 March 2012, <http:/ / finance.china.com.cn/roll/20120322/603508.shtml>, accessed 13 April 2012. 
efforts made by the JCG. Driven by the then Yoshihiko Noda government's purchase of Senkaku/Diaoyu Islands, the latest effort in August 2012 was unexpectedly successful. Though the Noda administration arrested the fourteen activists from China, Hong Kong and Macau for infringements of Japanese territory, ${ }^{62}$ they were later released within two days for fear of diplomatic backlash from China. Noteworthy here is that unlike before, the recent endeavor was a cause of alarm from for the Japanese as it demonstrated for the first time the unity among activists in Greater China and around the world for the cause of "Protection of Diaoyu Islands" movement. In the years ahead, we may witness more of such cases after the birth of a unified organization called World Chinese Alliance in Defense of the Diaoyu Islands in June 2012 for central coordination of demonstrations and island-landing efforts ${ }^{63}$ and the continuous Japan-China tensions after the islands' purchase as well as the Abe administration's unwavering stance on the Senkaku/Diaoyu Islands' issue. With these activities expected to be more intensified in the coming years, there is a possibility that the Japanese authorities will adopt strict measures to restrain what Tokyo views as Chinese civilian violation of its political legitimacy on these claimed islets.

Finally, there is also an upward trend in Chinese maritime enforcement activities after the September 2010 collision incident. The previous irregular trend in China's navigational missions in the East China Sea has fundamentally changed after the Senkaku Islands spat in September 2010. Within a short period of less than two years after the event, the Japanese defense ministry and the media had reported more than 15 cases of Chinese "patrolling" activities near and within the Japanese-claimed territorial waters between September 2010 and July 2012. Of these, three involved intrusions of the Chinese law enforcement ships into the Japanese-proclaimed territorial waters near Senkaku Islands: in August 2011, two Fisheries Law Enforcement Command (FLEC) patrol ships, Yuzheng 201 and Yuzheng 31001 entered the Japanese waters for the first time; in March 2012, one of the cutters belonging to the central government's State Oceanic Administration (SOA), Haijian 50, trespassed into Japan's claimed seas; and later in July, three occasions were reported by JCG of which four FLEC's patrol ships, Yuzheng-202, Yuzheng-204, Yuzheng-33001 and Yuzheng-35001, made new and repeated entries into these Tokyo-claimed waters. ${ }^{64}$

In the midst of the Sino-Japanese tension in September 2012 that was triggered by the former Noda Cabinet's successful purchase of the Senkaku Islands, the Chinese side rapidly dispatched up to 20 patrol vessels within a week as a form of sovereignty

62 Elizabeth Yuan, "After Flag Raising on Island, 14 Chinese Held in Japan," CNN News, 17 August 2012, <http:/ / edition.cnn.com/2012/08/16/world/asia/china-japan-islandsarrests>, accessed 18 August 2012.

63 Action Committee for Defending the Diaoyu Islands, "Shijie huaren baodiao lianmeng zhengshi chengli dahui juhui [The official mass meeting of World Chinese Alliance in Defense of the Diaoyu Islands]," 14 June 2012, <http:/ / forum.diaoyuislands.org/viewtopic.php?t=2873>, accessed 28 July 2012; “Noda $¥ 2$ billion Senkaku Offer Second in Line," Kyodo News, 1 August 2012, <http://www.japantimes.co.jp/text/nn20120801a4.html>, accessed 2 August 2012.

64 "China Boats Enter Waters Off Senkakus," Yomiuri Shimbun, 25 August 2011, <http:/ / www. yomiuri.co.jp/dy/national/T110824006192.htm>, accessed 1 September 2011; MOD Japan, Defense of Japan 2012 (Provisional Translation), July 2012, Tokyo, <http:/ / www.mod.go.jp/e/ publ/w_paper/pdf/2012/03_Column.pdf>, accessed 2 August 2012; “Another Chinese Patrol Ship Spotted Near Senkakus," Kyodo News, 13 July 2012, <http://www.japantimes. co.jp/text/nn20120713b5.html>, accessed 14 July 2012. 
assertion over the island chain. Unlike before, the move saw a record-breaking twelve maritime enforcement ships being deployed to Japan's territorial seas and contiguous zone within a single day (on September 18). ${ }^{65}$ From this day to the April 2013, there was at least fifteen voyages had been made by the Chinese marine ships and which in the latest mission, featured the fishery patrol ship, Yuzheng 206, the largest and most sophisticated vessel owned by the fishery administration authority thus far. At the same time, SOA's enforcement aircrafts have also reportedly flown over the Japanese-claimed airspace within the disputed territories ever since the first instance was detected in December 2012. ${ }^{66}$ These latest developments are certainly distinguishable from Beijing's previous small-scale ships' entries into the contented seas.

In the coming years, strengthening the Chinese maritime enforcement institutional and execution capacities remains the utmost priority of the central government. As of present, prominent government brains in China like Luo Yuan, are working on a plan to integrate all nine agencies that participate in the country's maritime enforcement activities, into a ministry led by the State Council's department, SOA; while the State (National) Oceanic Commission will be established to devise maritime strategies and to coordinate all key oceanic matters at the central governmental level. ${ }^{67}$ The latter central agency, in turn, is to be upgraded into a full ministry in the immediate future. In order to fortify the execution ability of the Chinese maritime enforcement forces, there is also a high possibility that the central leadership will transform the SOA's coastal police reserve unit into a coastal guard reserve force ${ }^{68}$ In the years ahead, we may witness the establishment of a Chinese maritime garrison which possesses both policing and military capabilities in the sea. Whilst decision has yet to be reached by the top leadership, the latest mutual cooperation agreement between the agency and the PLAN on personnel training and maritime surveillance and research ${ }^{69}$ seemed to confirm China's steady advancement toward the goal. It is Beijing's hope that the strengthened capacities in both institutional and execution structures will support its long-term goal of regularization of maritime enforcement missions in China's "sovereign waters" in the East and the

65 "Chinese Patrol Ships Leave Senkaku Waters," Kyodo News, September 24, 2012, <http:/ / www.japantimes.co.jp/text/nn20120924b1.html>, accessed 25 September 2012; and "Four Chinese Patrol Ships Spotted Near Senkakus but No Armada," Kyodo News, 24 September 2012, < http://www.japantimes.co.jp/text/nn20120920b5.html>, accessed 25 September 2012.

66 Xu Tianran, "Advanced Patrol Ship on Maiden Voyage Near Diaoyu," Global Times, 12 December 2012, <http://www.globaltimes.cn/NEWS/tabid/99/ID/749639/Advancedpatrol-ship-on-maiden-voyage-near-Diaoyu.aspx>, accessed December 13, 2012; and Defense of Japan 2013, p 40.

67 "Xuanshi "zhuquan" zhongguo haijian chuan donghai nanhai pa pa zou [Chinese patrol ships sailing in East China Sea and South China Sea as a show of sovereignty]," Lianhe Zaobao Online, 19 March 2012, <http://www.zaobao.com/wencui/2012/03/taiwan120319f.shtml>, accessed 28 March 2012; and "China to Restructure Oceanic Administration, Enhance Maritime Law Enforcement," Xinhuanet.com, 10 March 2013, < http://news.xinhuanet.com/english/ china/2013-03/10/c_132221768.htm>, accessed 12 March 2013.

68 "Zhongguo zhengwei yuan jianyi zujian haian jinbeidui [China's political commissar member proposed the formation of coastal guard reserve unit]," Rijing Zhongwen Wang [Nikkei Chinese Online], 7 March 2012, <http://cn.nikkei.com/china/cpolicssociety/1708-20120307.html>, accessed 28 March 2012.

69 "Xuanshi "zhuquan" zhongguo haijian chuan donghai nanhai pa pa zou [Chinese patrol ships sailing in East China Sea and South China Sea as a show of sovereignty]. 
South China Seas. Likewise, Beijing's maritime enforcement patrols are but another form of threat to Japan's political legitimacy of the claimed seas in the East China Sea.

\section{China's Growing Military Might vis-à-vis Taiwan}

Despite the constructive Cross-Strait atmosphere and closer socio-economic exchanges fostered by the Ma Ying-jeou administration since 2008, the Mainland China-Taiwan military distrust and stand-offs have not eased significantly. Largely due to its growing wealth, China, for the last decade or so, has devoted more resources to its military buildup vis-à-vis Taiwan as part of its unrealized unification goal. Similar to its economic sway over Taiwan, Beijing's continuous military build-up had shifted the overall military balance across the Strait in its favor in recent years and had risked Taipei to mainland's armed subjugation. As pointed out by Taiwan's Ministry of Defense in 2008, Beijing has been acquiring capabilities far more than what it needs for the use of force against Taipei. ${ }^{70}$ In Taiwan's National Defense Report 2011, the PLA has roughly ten times the number of armed personnel than the approximately 270,000-men Taiwanese forces; possesses absolute edge in ballistic missiles where the latter has no unit equivalent to the former's second artillery corps as well as trailing far behind China's naval and air inventory of having over 60 submarines, 930 battleships, 40 amphibious ships and more than 1,860 jet fighters. ${ }^{71}$ Moreover, if the official 2011 military budgets of both countries are compared, Beijing's huge expenditure has clearly dwarfed Taipei's US \$ 9 billion by more than 14 -fold. ${ }^{72}$ Of course, not to mention the large disparity between these two states if China's actual (or unofficial) defense budget is taken into account.

Second, as compared to before, the PLA has greatly increased its military preparedness for the purpose of military action across the Strait. The PLA has reportedly conducted training and exercises of the ground forces for island control purposes, enhancing its target guidance and attack capacities of its naval and air forces and most importantly, perfecting its Second Artillery's precision strike abilities. The Chinese military also expanded its military operational units by including the Armed Police for participation in emergency combat operations in 2007 as well as retaining a record number of missiles deployed against Taiwan at more than 1,600 despite Premier Wen Jiabao's earlier hint to reduce them in September 2010. ${ }^{73}$ All these measures have greatly boosted the PLA's capabilities to successfully execute its military offensive operations against the island. If we take these two factors together, it is certainly not improbable to

\footnotetext{
70 Russell Hsiao L. C., "China's Military Budget Spurs Debate over the Taiwan Strait," China Brief, Vol. 8, No. 6, 14 March 2008, <http://www.jamestown.org/programs/chinabrief/ single/?tx_ttnews[tt_news] $=4788 \& t x \_t$ tnews[backPid] $=168 \&$ no_cache $=1>$, accessed 30 May 2012.

71 Ministry of National Defense (MND) Republic of China (ROC), 2011 ROC National Defense Report, Taipei: MND, 2011, pp 81-83, <http://2011mndreport.mnd.gov.tw/en/ pdf/100report_english.pdf>, accessed 1 August 2012.

722011 ROC National Defense Report, p 81.

732011 ROC National Defense Report pp 77-83; “Taiwan Deploys Missile against China," Taiwan News, 30 May 2012, <http:/ / www.etaiwannews.com/etn/news_content.php?id=1933368>, accessed 1 August 2012; and "China Could Pull Some Missiles Targeting Taiwan," Global Security Newswire, 6 April 2011, <http://www.nti.org/gsn/article/china-could-pull-somemissiles-targeting-taiwan/>, accessed 1 March 2012.
} 
claim that China actually has attained the required de facto "military dominance" over Taiwan. Whether Beijing will use such force to affect any change of tides in the Taiwan Straits in the future is a question that depends on the extent of the island's economic integration with China and the Taiwanese politicians' approach in relations to Beijing.

Japan's primary concern, however, derives from one of the PLA's potential offensive scenario, that is, Beijing's sea and air blockade of ports, offshore islands and sea lanes surrounding Taiwan. Any area denial of this sort during a military crisis is bound to affect not only the island's economic survival ${ }^{74}$ but also that of its neighboring Japan. In addition, China may also activate its anti-access defense plan in the open seas to prevent successful entry/employment of US-Japan military forces into the Taiwan war theatre. As much as it is important to Beijing, Taiwan and its surrounding seas stand in the middle of the sea lane of commerce (SLOC) crucial for the Middle East's oil and iron ore imports to Japan. With 90 per cent of Japan's oil shipments passing through the deep waters Bashi Channel to the east of Taiwan, the Chinese blockade of these crucial sea lanes during cross-Strait military conflict or even after gaining control of Taiwan will certainly put Japan's economic survival at stake, ${ }^{75}$ let alone economic dominance in the region. Besides, Japan does not want to see further expansion of Chinese militarism. In case China occupies Taiwan, it will gain access to excellent bases and port facilities near open seas to host its submarine fleet needed for its projection power far beyond the second island chain. ${ }^{76}$ From a broader outlook, this will eventually upset the existing military balance between US-Japan/Japanese military forces and the PLA.

In the next four years or so, it is highly likely that China will continue to dominate its relations with Taiwan instead of the other way round. Though there is no guarantee that the current positive engagement policy toward the Mainland by Taiwan will not change albeit slightly after the end of Ma's presidency and in the event the opposition, Democratic Progressive Party (DPP) regains its political power, recent developments have pointed to the fact that China's hard power, be it military or economic, is simply too difficult for a small island-state like Taiwan to resist. The DPP's reinstatement of the Department of China Affairs in July 2012 and its key party leader, Frank Hsieh's visit to China in October $2012^{77}$ is a clear recognition from the pro-independence opposition party on the role Beijing plays in the island's economic future and the need even for

74 Ministry of National Defense ROC, 2011 ROC National Defense Report, $\mathrm{p} 80$. The report specified that joint military blockade is one of the five military options that the PLA might pursue in the use of force against Taiwan. The others are joint fire support attack, joint landing, area denial and joint military intimidation.

75 Shaohua Hu, "Japan and the Cross-Taiwan Strait Conflict," Journal of Chinese Political Science, Vol. 11, No. 2, Fall 2006, p 90; Hisahiko Okazaki, "The Strategic Value of Taiwan", paper presented for US-Japan-Taiwan Trilateral Strategic Dialogue, Tokyo, Japan, 2 March 2003.

76 Tomohiko Taniguchi, "A Cold Peace: The Changing Security Equation in Northeast Asia," Orbis, Vol. 49, No. 3, Summer 2005, p 456.

77 Jenny Hsu W. and Aries Poon, "Taiwan Opposition Leader Willing to be 'Flexible' with China," The Wall Street Journal, 1 August 2012, <http:/ / online.wsj.com/article/SB1000087 2396390443687504577562264020633628.html>, accessed 14 August 2012; "Hsieh May Visit China Again Early Next year: Report," Want China Times, 3 November 2012, <http:/ / www. wantchinatimes.com/news-subclass-cnt.aspx?id=20121103000102\&cid=1101>, accessed 12 December 2012. The department was reinstated after the election of Su Tseng-chang as the DPP's chairman in May 2012. Su revealed that he is willing to have pragmatic cooperation with Beijing though he remained committed to its pro-independence position. 
the hard-line secessionists to for engagement despite having different ideological differences. China's rising influence across the straits, therefore, forces Taiwan to "foster functional framework for cross-Strait relations", one that successive administrations in Taipei have to adhere to, or risk confrontation with the mainland.

\section{Conclusion: The Sino-Japanese Threat Perceptions that Affect Regional Security Cooperation}

Japanese politicians, members of the defense circle (and to a certain extent, the American military officials and experts) and the media view China's expansionism in both the military and the non-military fronts, as a larger development that seeks to threaten Japan's military, political and economic securities at large. The first facet of threat, China's military ascendancy, translated in the forms of rising military budget and military modernization for offshore defense, destabilizes the military balance configuration that currently favors the Japanese defense forces in the East China Sea and US-Japan collective forces in the wider East Asian region. It is therefore, an indirect threat toward Japan's military security. Particular emphasis, too, has to be given to increasing PLA's military activities in the areas surrounding Japan, where it threatens not only Japan's military security, but also the political security of the country. On the other hand, growing Chinese maritime enforcement and civilian activities in the contented East China Sea jeopardizes the Japanese national security in a much broader way. Though less precarious than the Chinese military challenge, such threat challenges both Japan's political and economic securities in the long-run. Overall, the Japanese administration comprising the ruling Liberal Democratic Party (LDP) and the opposition Democratic Party of Japan (DPJ), perceives China's expansionism as a phenomenon that threatens Japan's national security in a multi-dimensional way. 